\title{
Eleições legislativas no Porto (1895 e agosto de 1906)
}

Tiago Reis

tiago-reis@outlook.com

\section{Resumo}

As grandes questões de investigação formuladas no âmbito do tema em estudo são três. A primeira diz respeito aos diplomas eleitorais que regularam as eleições legislativas de 1895 e 1906 (aqui são abordados os decretos de 28 de março de 1895 e de 4 de agosto de 1901). A segunda prende-se com o modo como os governos monárquicos "fabricavam" vitórias eleitorais, salientando o caciquismo como instrumento de manipulação do voto. A terceira grande questão de investigação relaciona-se com a análise da cobertura jornalística dada pelos jornais portuenses $O$ Comércio do Porto e A Voz Pública (fontes selecionadas para a redação deste artigo) às eleições legislativas de 1895 e de 1906 na cidade do Porto, eleições estas que se constituem como o objeto de estudo deste artigo.

Os atos eleitorais acima referidos foram selecionados para esta investigação na medida em que, por um lado, não se lhes encontrava associada uma explicação óbvia para os resultados registados no Porto e, por outro, seria interessante compreender como se processava um ato eleitoral no fim do século XIX e no princípio do século XX. Por essa razão, tornou-se interessante estudar o contexto da sua realização.

Palavras-chave: Eleições, Porto, sistemas eleitorais, imprensa.

\begin{abstract}
There are three major research questions within the scope of the subject under study. The first concerns the electoral diplomas that regulated the legislative elections of 1895 and 1906 (the decrees of 28th March 1895 and 4th August 1901 are covered here). The second is related to the way in which the monarchic governments "manufactured" electoral victories, emphasizing the caciquismo as an instrument of manipulation of the vote. The third major research question is related to the analysis of the journalistic coverage given by the Porto newspapers O Comércio do Porto and A Voz Pública (sources selected for the writing of this article) to the legislative elections of 1895 and 1906 in the city of Porto, elections that constitute the object of study of this article.

The aforementioned electoral acts were selected for this investigation as, on the one hand, there was not an obvious explanation for the results recorded in Porto and, on the other hand, it would be interesting to understand how an electoral act took place at the end of the XIX century and at the beginning of the XX century. For this reason, it became interesting to study the context of its realization.
\end{abstract}

Keywords: Elections, Porto, electoral systems, press. 


\section{Introdução}

Considerando os três subtemas de investigação propostos, selecionei o que se refere à Monarquia Constitucional, sendo o tema definitivo selecionado para esta investigação: «Eleições legislativas no Porto (1895 e agosto de 1906)».

Os atos eleitorais acima referidos foram selecionados para esta investigação na medida em que, por um lado, não se lhes encontrava associada uma explicação óbvia para os resultados registados no Porto e, por outro, seria interessante compreender como se processava um ato eleitoral no fim do século XIX e no princípio do século XX. Por essa razão, tornou-se interessante estudar o contexto da sua realização.

As grandes questões de investigação formuladas no âmbito do tema em estudo são três. A primeira diz respeito aos diplomas eleitorais que regularam as eleições legislativas de 1895 e 1906 (aqui são abordados os decretos de 28 de março de 1895 e de 4 de agosto de 1901). A segunda prende-se com o modo como os governos monárquicos "fabricavam" vitórias eleitorais, salientando o caciquismo como instrumento de manipulação do voto. A terceira grande questão de investigação relaciona-se com a análise da cobertura jornalística dada pelos jornais portuenses $O$ Comércio do Porto e $A$ Voz Pública (fontes selecionadas para a redação deste artigo) às eleições legislativas de 1895 e de 1906 na cidade do Porto.

No que diz respeito às fontes hemerográficas que utilizamos, $O$ Comércio do Porto "foi fundado [...] $1854[\ldots]$ com o nome de O Comércio [...]. Sete meses depois [...] passou a ser diário e, um ano mais tarde, adotou a designação O Comércio do Porto..."1.

No estatuto editorial do jornal "vinha explícito que pretendia ser uma voz do Norte, capaz de interpretar os anseios da população. Assim, assumiu-se como um jornal de comércio, agricultura e indústria", , velando, sobretudo, pelos interesses empresariais portuenses. Cessou a sua atividade em julho de 2005 .

Relativamente ao jornal $A$ Voz Pública, este saiu para as bancas ao longo da sua existência sob duas designações distintas: A República (de 19 de abril de 1890 a 8 de maio de 1891) e $A$ Voz Pública (de 9 de maio de 1891 a 30 de setembro de 1909). A mudança de título do periódico resultou da ação repressiva do poder político sobre a imprensa republicana na sequência da revolta de 31 de janeiro de 1891, na cidade do Porto, no âmbito da qual se efetuou uma primeira tentativa de instaurar o regime republicano em Portugal. O jornal teve como gerente Elísio Castro e como diretor José Bessa de Carvalho (nas edições de 1895) e como editor Domingos

\footnotetext{
${ }^{1}$ O Comércio do Porto in Artigos de apoio Infopédia [Em Linha]. Porto: Porto Editora, 2003-2019.
}

${ }^{2}$ Idem. 
Gomes Gaspar (nas edições de 1906) e sedes na travessa de Passos Manuel, nº 19 a 23 (nas edições de 1895) e na rua de Santo António, nº 184 - A (por altura das edições de 1906).

Este jornal diário da esquerda republicana tinha como principais características: uma forte oposição ao regime monárquico (patente logo nos seus editoriais) que era muito mais contundente do que qualquer das críticas ao rei e aos políticos da monarquia que pudessem ser expostas também no jornal de cariz monárquico ("monárquico" pelo menos até à revolução de 5 de outubro de 1910) O Comércio do Porto; um inegável papel na dinamização da propaganda republicana no Porto (contando com numerosos correspondentes que faziam chegar à redação, no Porto, as principais notícias das terras em que se encontravam, incluindo informações relacionadas com a realização de conferências e comícios das estruturas republicanas locais, como a Comissão Municipal Republicana do Porto, com a divulgação das listas de candidatos republicanos pelos círculos eleitorais em que o Porto se inseria, nomeadamente o círculo $\mathrm{n}^{\mathrm{o}} 5$, correspondente ao Porto Oriental e o círculo $\mathrm{n}^{\mathrm{o}}$ 6, relativo ao Porto Ocidental); a vontade de, enquanto órgão da imprensa local, alcançar uma posição nacional, contando com numerosos correspondentes em várias zonas do país, incluindo Lisboa (de onde enviavam informações relativas às ações de propaganda republicana e aos resultados eleitorais das legislativas e municipais na capital portuguesa); e, finalmente, caracterizava-se ainda pela defesa dos interesses dos operários e por uma maior atenção aos problemas sociais.

\section{Contexto histórico}

\subsection{A ascensão do republicanismo}

De acordo com Manuel M. Cardoso Leal, "a vitória do Partido Republicano no círculo de Lisboa, alcançada em março de 1890, com a ajuda informal dos progressistas, no ambiente crítico que se seguiu ao «Ultimato Inglês», foi melindrosa para o regime"3.

Observando a tabela abaixo é possível percecionar dinâmicas na evolução dos resultados eleitorais republicanos ao longo das décadas finais do século XIX:

\footnotetext{
${ }^{3}$ LEAL, Manuel M. Cardoso - "Eleições na Monarquia Constitucional: governos, partidos e opinião pública (1852-1910)". História. Revista da FLUP. [Em Linha] Porto. IV Série, vol. 9, n. 2 (2019) p. 47-48.
} 
Tabela 1 - Evolução da representação parlamentar republicana

\begin{tabular}{|c|c|c|}
\hline Data das eleições & N.o de deputados & Círculos Eleitorais \\
\hline 13 de outubro de 1878 & 1 & Porto \\
\hline 19 de outubro de 1879 & 1 & Porto \\
\hline 21 de agosto de 1881 & 1 & Lisboa \\
\hline 29 de junho de 1884 & 2 & Lisboa \\
\hline 6 de março de 1887 & 2 & Lisboa \\
\hline 20 de outubro de 1889 & 2 & $\begin{array}{l}\text { Lisboa (1) } \\
\text { Porto (1) }\end{array}$ \\
\hline 30 de março de 1890 & 4 & $\begin{array}{c}\text { Lisboa (3) } \\
\text { Acumulação (1) }\end{array}$ \\
\hline 23 de outubro de 1892 & 3 & $\begin{array}{c}\text { Lisboa (2) } \\
\text { Porto (1) }\end{array}$ \\
\hline 15 de abril de 1894 & 2 & Lisboa \\
\hline 17 de novembro de 1895 & - & - \\
\hline 2 de maio de 1897 & - & - \\
\hline 26 de novembro de 1899 & 3 & Porto \\
\hline 25 de novembro de 1900 & - & - \\
\hline 6 de outubro de 1901 & - & - \\
\hline 26 de junho de 1904 & - & - \\
\hline 12 de fevereiro de 1905 & - & - \\
\hline 29 de abril de 1906 & 1 & Lisboa \\
\hline 19 de agosto de 1906 & 4 & Lisboa \\
\hline 5 de abril de 1908 & 7 & $\begin{array}{c}\text { Lisboa (4) } \\
\text { Beja (1) } \\
\text { Setúbal (2) }\end{array}$ \\
\hline 28 de agosto de 1910 & 14 & $\begin{array}{c}\text { Lisboa (11) } \\
\text { Beja (1) } \\
\text { Setúbal (2) }\end{array}$ \\
\hline
\end{tabular}

FONTE: PROENÇA, Maria Cândida - D. Manuel II. Rio de Mouro: Círculo de Leitores, 2005, p. 35-36.

Da análise da Tabela 1, percebe-se que há um padrão que une as eleições legislativas nas quais o número de deputados republicanos eleitos foi mais expressivo: todos esses sufrágios ocorreram em momentos em que a conjuntura económica, política ou social foi particularmente dura. Atente-se no seguinte: as eleições de 30 de março de 1890 foram as primeiras imediatamente após o ultimato britânico; as de 23 de outubro de 1892 decorreram ainda em clima de grande pressão económica e social devido aos efeitos da bancarrota parcial de Portugal; o sufrágio realizado em 26 de novembro de 1899 reflete na votação republicana o efeito do descontentamento da população do Porto com o Governo então em funções devido ao 
modo como este procedeu para conter o surto de peste bubónica na cidade; as eleições de 19 de agosto de 1906 decorreram durante o período agitado da governação de João Franco; as de 5 de abril de 1908 tiveram lugar escassos dois meses após o regicídio de 1 de fevereiro num acentuado clima antimonárquico; finalmente, nas de 28 de agosto de 1910 os republicanos duplicaram a sua votação face ao sufrágio imediatamente anterior, elegendo catorze parlamentares à Câmara dos Deputados, o que pode ser explicado se se tiver em conta que a eleição decorreu pouco mais de um mês antes da revolução que implantou a República em Portugal com tudo o que isso significa em termos políticos. Por isso, e descontando naturalmente as situações de negociação de lugares entre os partidos monárquicos dominantes e os dirigentes republicanos, o efeito do voto de protesto pode estar presente nos resultados do Partido Republicano Português.

Nas palavras dos autores da Nova História de Portugal,

já quanto ao Partido Republicano, é possível avaliar do seu crescimento e da sua implantação ao longo do primeiro decénio do século XX. Nos círculos eleitorais do Sul - distritos de Lisboa, Setúbal, Santarém, Portalegre, Évora, Beja e Leiria -, a votação republicana aumentou consideravelmente entre 1906 e 1910, com relevo para os círculos de Lisboa, Setúbal e Beja, onde foi possível eleger deputados. Este facto vem confirmar a dicotomia, já tantas vezes apontada, entre o Norte e o Sul do Portugal da época. ${ }^{4}$

\subsection{Problemas da Monarquia Constitucional no reinado de D. Carlos}

D. Carlos é aclamado rei de Portugal em dezembro de 1889 sucedendo ao pai, o rei D. Luís. No mês imediatamente a seguir ao início do seu reinado, D. Carlos vê-se confrontado (a 11 de janeiro) com uma grave crise diplomática: o Ultimato feito pelo Governo da Grã-Bretanha ao governo português. As consequências fizeram-se sentir essencialmente nos domínios político e social. De tal forma que muitos autores assinalam o Ultimato como o evento que marca o início da fase final da monarquia constitucional portuguesa.

Acontecimentos como a bancarrota de 1891-1892 e a ditadura de João Franco (19071908), o forte embaraço sentido pela Casa Real e (sobretudo) pelo monarca devido à questão dos adiantamentos (no âmbito da designada «Lista Civil») feitos à margem da lei e do parlamento durante vários anos pelos sucessivos governos, o crescente desgaste da monarquia provocado pela propaganda republicana e, de modo geral, a postura excessivamente interventiva de D. Carlos nos assuntos da governação (nomeando e demitindo governos; dandolhes condições artificiais para poderem governar, através da nomeação de «fornadas de pares» que lhes assegurassem amplas maiorias na Câmara dos Pares sempre que necessário e, com

\footnotetext{
${ }^{4}$ MARQUES, A. H. de Oliveira (coord.) - Portugal da Monarquia para a República. In SERRÃO, Joel e MARQUES, A. H. de Oliveira (dir) - Nova História de Portugal. Lisboa: Editorial Presença. Vol. XI, p. 421.
} 
isso, granjeando a simpatia de muitos políticos e o azedume de outros tantos) contribuíram para o progressivo descrédito do regime monárquico junto do eleitorado em particular e da população portuguesa em geral.

A etapa final da crise do rotativismo monárquico consuma-se entre 1901 e 1906 quando novos partidos (com uma organização mais estruturada que inclui programas políticos, direções partidárias eleitas e redes de militantes) surgem no sistema político português: João Franco abandona o Partido Regenerador para fundar o Partido Regenerador Liberal, Jacinto Cândido da Silva cria o Partido Nacionalista, José Maria de Alpoim dá origem à Dissidência Progressista e a geração de estudantes revolucionários de 1890 revitaliza o Partido Republicano Português 5 .

Tudo culminaria no regicídio de 1 de fevereiro de 1908, na aclamação do infante D. Manuel como rei de Portugal (como D. Manuel II) em maio do mesmo ano e, finalmente, na revolução que implantou a República em Portugal em 5 de outubro de 1910.

\section{Sistemas eleitorais vigentes à data das eleições legislativas de 1895 e 1906}

No período constitucional monárquico, de acordo com a entrada "sistemas eleitorais" do Dicionário de História de Portugal,

houve 22 diplomas sobre matéria eleitoral, dos quais 2 instruções (1820 e 1826), 13 decretos (1834, 1835, 4 de Junho e 8 de Outubro de 1836, 1842, 1846, 1847, 1851, 1852, 1856, 1869, 1895 e 1901) e 7 leis $(1822,1838,1859,1878,1884,1896$ e 1899). A análise das disposições eleitorais ficaria incompleta se não tentássemos determinar o grau em que, na prática, elas favoreceram ou restringiram a participação da população no acto político mais importante do cidadão em regime representativo. Nas actuais condições da investigação histórica no nosso país não poderemos ir muito longe nesta sondagem, que se nos afigura fundamental para a compreensão de muitos aspectos da nossa história oitocentista. ${ }^{6}$

Ainda de acordo com o mesmo autor,

entre as críticas de pendor republicano que atingem os sistemas eleitorais da monarquia representativa, registe-se a de Teófilo Braga (Soluções Positivas, vol. I, p. 115): 'Ao fim de meio século de constitucionalismo em Portugal, chega-se à conclusão histórica de que nunca existiu uma câmara de deputados que não proviesse da candidatura oficial e que, apesar de uma ininterrompida maioria, nunca ministério algum entrou ou saiu do poder por indicação parlamentar, mas pelo arbítrio do poder moderador. Quem se der ao trabalho de formar uma estatística desde 1834 até hoje para observar a evolução da representação nacional e dos ministérios, chega a este resultado compungente, demonstrado pela severidade implacável dos números. Temos o regime absoluto em essência, porém mascarado com o formalismo caro e dissolvente do sistema parlamentar que serve para iludir os incautos na sua ingenuidade. ${ }^{7}$

\footnotetext{
${ }^{5}$ RAMOS, Rui (coord.) - A Segunda Fundação (1890-1926). In José Mattoso (dir.) - História de Portugal. Lisboa: Editorial Estampa, 1994. Vol. 6, p. 223.

${ }^{6}$ TENGARRINHA, José - "Sistemas eleitorais”. In SERRÃO, Joel (dir.) - Dicionário de História de Portugal. Lisboa: Iniciativas Editoriais, 1971. Vol. IV, p. 6.

${ }^{7}$ Idem, ibidem.
} 


\title{
2.1. O Decreto de 28 de março de 1895
}

Referindo-me ao caso concreto das eleições legislativas de 17 de novembro de 1895 , as mesmas decorreram ao abrigo do decreto (publicado em ditadura pelo governo regenerador presidido por Hintze Ribeiro e com João Franco como ministro do Reino) de 28 de março de 1895. Assim,

\begin{abstract}
a lei de 1884 [lei Barjona de Freitas] é revogada, no sentido centralizador e autoritário, pelo Decreto de 28 de Março de 1895 (Hintze-Franco), que adopta a solução mais simples para que o governo tenha controle apertado sobre o acto eleitoral: a área dos círculos, plurinominais, coincidia com a dos [dezassete] distritos administrativos, sem representação de minorias e sem que as cidades de Lisboa e Porto fossem destacadas dos seus distritos. Quanto à capacidade eleitoral, o decreto estabelecia serem eleitores os cidadãos portugueses, maiores de 21 anos, que pagassem contribuições directas não inferiores a 500 réis ou que soubessem ler e escrever. Esta disposição eleitoral e as que se lhe seguem só poderão ser correctamente interpretadas à luz das dificuldades crescentes em que se debatia o regime monárquico em Portugal. Com efeito, as leis eleitorais da Monarquia mostram-se especialmente interessadas em afastar da Câmara o seu mais perigoso opositor, o Partido Republicano, cuja projecção e dinamismo revolucionário aumentam constantemente nesse último decénio do século. ${ }^{8}$
\end{abstract}

Segundo Maria Filomena Mónica, o decreto em referência fazia diminuir o número de deputados dos cento e setenta então em funções para os cento e vinte, "reorganizava (...) os recenseamentos (...) alargava as inelegibilidades (...) fixava um número máximo para a representação de certas classes (...) ressuscitava o escrutínio por lista em todo o país"9 . Pedro Tavares de Almeida é mais preciso no que toca ao número máximo de funcionários públicos que podiam ser eleitos para a Câmara dos Deputados, que correspondia a quarenta, bem como em relação ao número de advogados e médicos (vinte deputados) a eleger. Esta limitação numérica foi abolida pela lei de 21 de setembro de $1897 .{ }^{10}$

\subsection{O Decreto de 4 de agosto de 1901}

No caso das eleições legislativas realizadas a 19 de agosto de 1906, estas regeram-se por aquele que foi o último diploma eleitoral da Monarquia Constitucional portuguesa e que ficou conhecido pela depreciativa designação de "ignóbil porcaria" que lhe foi emprestada por João Franco, já não regenerador, mas líder do Partido Regenerador-Liberal.

Refiro-me ao Decreto de 4 de agosto de 1901, de acordo com o qual o sufrágio era direto e secreto, o direito de voto e os critérios de elegibilidade como deputado não sofriam alterações face ao diploma eleitoral anterior, o número de deputados previsto para a Câmara dos Deputados era de cento e quarenta e oito (em Portugal Continental e nas Ilhas Adjacentes) a

\footnotetext{
${ }^{8}$ Idem, ibidem.

${ }^{9}$ MÓNICA, Maria Filomena - “As Reformas Eleitorais no Constitucionalismo Monárquico, 1852-1910”. Análise Social, vol. XXXI, n. ${ }^{\circ} 131$ (1996) p. 1064.

${ }^{10}$ ALMEIDA, Pedro Tavares de - Legislação Eleitoral Portuguesa, 1820-1926. Lisboa: Imprensa Nacional - Casa da Moeda, 1998, p. 723-729.
} 
eleger por vinte e seis círculos plurinominais e de acordo com um regime de escrutínio de voto limitado ou de lista incompleta (em que o eleitor vota num número de nomes inferior ao dos deputados a eleger no correspondente círculo) ${ }^{11}$.

Maria Filomena Mónica afirma que:

a 8 de Agosto de 1901, durante as férias parlamentares, Hintze publicava um decreto eleitoral. O país era dividido em grandes círculos plurinominais, com as cidades de Lisboa e Porto desenhadas de forma que os votos urbanos fossem anulados pelos rurais. Além disso, o decreto suprimia as comissões de recenseamento, relativamente independentes, substituídas por comissões de funcionários públicos. A reforma destinava-se, sem margem para dúvidas, a impedir uma aliança em Lisboa entre franquistas e republicanos. [...] Para agradar aos Progressistas, Hintze decidiu restaurar a representação de minorias, extintas desde 1895, e aumentar o número de deputados. [...] Mais do que contra os Republicanos, o decreto era contra Franco. A lei de 1901 manteve-se até 1910, quando a monarquia foi derrubada, na Rotunda, por um bando de sargentos e populares. ${ }^{12}$

\subsection{Como os governos monárquicos "fabricavam" vitórias eleitorais: o} caciquismo como instrumento de manipulação do voto

As eleições de deputados na Monarquia Constitucional, especialmente na segunda metade do século XIX, não tinham por objetivo fazer corresponder a composição do parlamento à vontade livre e conscientemente expressa pela população portuguesa no momento do sufrágio (até porque, convém não esquecer, o direito de voto estava reservado a, entre outras condições, quem soubesse ler e escrever e era censitário, isto é, só tinha acesso a esse direito político quem auferisse determinado nível de rendimento anual, pagando a correspondente proporção de impostos, fator que excluía automaticamente largos setores da população) mas sim proporcionar vitórias ao partido no governo à data da eleição legislativa e dotá-lo do apoio político de uma robusta maioria de parlamentares na Câmara dos Deputados que lhe permitisse governar com completa estabilidade. Na prática, o monarca nomeava o chefe do governo e, de seguida, eram convocadas eleições para conferir uma aura de legitimidade "democrática" a essa nomeação feita pelo Rei. Dito de outra forma: os atos eleitorais serviam para legitimar uma situação política preexistente ${ }^{13}$.

No contexto da disputa eleitoral, não estavam em causa programas políticos diferenciados com vista à melhor governação possível do reino mas sim a satisfação dos interesses da fação então no Poder. Esta era uma realidade transversal aos partidos da Monarquia que, se necessário fosse, chegavam ao ponto de combinar os resultados eleitorais: o chefe do governo negociava com o líder do principal partido da oposição (geralmente num

\footnotetext{
${ }^{11}$ Idem, p. 723-729.

12 MÓNICA, M. F. - “As Reformas Eleitorais no Constitucionalismo Monárquico, 1852-1910”... pp. 1068-1070.

${ }^{13}$ LOPES, Fernando Farelo - "Caciquismo e Política em Portugal. Uma perspectiva sobre a Monarquia e a I República”. Sociologia - Problemas e Práticas, n. 9 (1991) pp. 127-137.
} 
binómio Partido Regenerador - Partido Progressista) quantos deputados caberia a cada um ainda antes da realização das eleições correspondentes ${ }^{14}$. $\mathrm{O}$ verdadeiro instrumento para conseguir os resultados pretendidos neste tipo de votações, sem menosprezar evidentemente as cíclicas revisões da lei eleitoral e os "acordos de cavalheiros" que acabei de referir, consistia numa vasta rede de influentes locais (quer nas cidades, quer no mundo rural) agregados aos dois partidos do rotativismo e que, dito de modo sucinto, "compravam", por vezes literalmente, o voto de pessoas que deles dependiam de diversas maneiras.

\section{Maria Filomena Mónica fala de}

uma instituição, o caciquismo, que em muito contribuiu para solidificar o regime. O cacique tem sido das personagens mais vilipendiadas da história política. Ele constituiu, todavia, a forma encontrada pelas comunidades rurais para fazer chegar junto do Estado as suas aspirações. As eleições, directas a partir de 1852, continuaram na prática a funcionar como se fossem indirectas. O candidato a deputado conquistava o favor do «influente» e este convencia os dependentes a votarem nele. Num país católico, onde o «padrinho» era uma instituição, isto era, e parecia, natural. Ao contrário do que sucedia nalguns países do Norte da Europa, onde os cidadãos começavam a reagir contra os «vexames», a noção de cidadania só existia, em Portugal, no espírito de alguns iluminados. ${ }^{15}$

\section{Continua a autora:}

o caciquismo consagrava uma relação desigual, mas os favores passavam em ambos os sentidos. É, aliás, importante distinguir o caciquismo, baseado na troca de favores, dos atropelos administrativos verificados durante o acto eleitoral, de que o mais conhecido era a «chapelada». O primeiro era tido como normal; apenas o segundo era visto como a fraude que efectivamente era. ${ }^{16}$

Maria Filomena Mónica refere, também, que: "sendo o voto secreto em Portugal [...], alguma coisa o povo conseguia através deste mecanismo. Os poderosos careciam de quem votasse neles. O povo podia e fazia chantagem sobre quem the pedia o voto"17. Por fim, e no mesmo artigo, a autora afirma que "para os sectores modernizadores, o balanço era negro: ' $\mathrm{O}$ deputado não é livre. O círculo impõe-se [...]. O deputado pode votar tudo, menos o que fizer mal ao que o elegeu, embora isso faça bem à sociedade" $" 18$.

Sobre o tema do caciquismo, Fernando Farelo Lopes assinala que "o poder do cacique numa determinada circunscrição nutria-se da sua capacidade para distribuir bens e serviços por um núcleo mais ou menos reduzido de seguidores ou clientes"19. O autor sublinha que esta relação entre cacique e cliente funcionava numa lógica de transação mútua. $O$ que proporcionava o influente local ao seu cliente? Oferecia

\footnotetext{
${ }^{14}$ Idem, ibidem.

${ }^{15}$ MÓNICA, M. F. - “As Reformas Eleitorais no Constitucionalismo Monárquico, 1852-1910”... p. 1071.

${ }^{16}$ Idem, ibidem.

${ }^{17}$ Idem, ibidem.

${ }^{18}$ Idem, p. 1048.

${ }^{19}$ LOPES, F. F. - “Caciquismo e Política em Portugal. Uma perspectiva sobre a Monarquia e a I República”... p. 128.
} 
empregos e meios básicos de subsistência; a segurança perante situações de miséria económica ou de doença; a protecção ante o banditismo, os inimigos pessoais e as ameaças públicas (polícias, tribunais, agentes fiscais, serviço militar, etc.). Os caciques garantiam ainda serviços de natureza colectiva (estradas, pontes, escolas...). ${ }^{20}$

Como retribuía o cliente ao cacique os favores por este prestados? Com

o contributo em trabalho para as terras ou empresas do patrono (embora inserido numa relação distinta da que se reporta ao contrato impessoal); o fornecimento de serviços e bens suplementares para a casa deste, os quais podiam ser substanciais ou possuir um valor meramente simbólico enquanto expressão de deferência; a promoção dos interesses públicos do cacique: desde a defesa da sua reputação até à prestação de informações, passando pelo apoio político e eleitoral. ${ }^{21}$

No entanto, o que a realidade também demonstrava era que, com frequência, os “influentes locais são meros clientes de influentes situados mais acima, os quais, por sua vez, servem influentes em lugar superior, e assim sucessivamente até se formar uma cadeia de redes caciquistas a nível nacional”22. Ainda seguindo esta linha de raciocínio, Farelo Lopes esclarece, citando, que no regime monárquico

o dirigente distrital do partido, que pode exercer o cargo de governador civil quando a sua organização se encontra no poder, é uma figura crucial de uma cadeia cujo topo é o líder partidário - que ocupa quase invariavelmente, quando no poder, o cargo de presidente do Ministério, acumulando, muitas vezes, com a pasta política, o Ministério do Reino - e cuja base reside nos influentes de freguesia ou de aldeia. ${ }^{23}$

O mesmo autor revela também (citando a terminologia de J. Varela Ortega) que o principal tipo de caciquismo na monarquia era o "caciquismo burocrático" ou "do Terreiro do Paço" que se alicerçava nos recursos estatais, num panorama em que o erário público era colocado ao serviço de interesses particulares.

Concluindo este ponto, interessa sublinhar que o desinteresse da maioria da população pela vida política do reino (por um conjunto de fatores) era o combustível de que se alimentava esta viciação constante dos processos eleitorais.

\section{Eleições legislativas no Porto no reinado de D. Carlos (1889-1908)}

\subsection{As eleições de deputados na imprensa local}

No que diz respeito à questão de investigação «As eleições de deputados na imprensa local», há que fornecer uma pequena explicação sobre o aspeto metodológico.

Nesta investigação, optei por estabelecer uma comparação entre dois atos eleitorais ocorridos em momentos distantes entre si no tempo, mais concretamente as eleições legislativas de 17 de novembro de 1895 e de 19 de agosto de 1906. Recorrendo à técnica de painel,

\footnotetext{
${ }^{20}$ Idem, ibidem.

${ }^{21}$ Idem, ibidem.

${ }^{22}$ Idem, p. 129.

${ }^{23}$ Idem, ibidem.
} 
selecionei dois jornais diários existentes nos dois anos acima referidos e portadores de ideologias políticas antagónicas (o Comércio do Porto, monárquico, e A Voz Pública, republicano), com vista a analisar a cobertura jornalística dada por ambos aos atos eleitorais para a Câmara dos Deputados acima mencionados. De seguida, estabeleci o período que me era mais conveniente para efeitos de análise: de 17 de outubro de 1895 a 24 de novembro de 1895 e de 19 de julho de 1906 a 26 de agosto de 1906. Por uma questão de segurança, decidi alargar o período de análise de duas semanas antes do dia das eleições para um mês; observei, igualmente, um período de uma semana após o dia do ato eleitoral.

Depois de efetuar esta observação relativamente alargada, selecionei cinco dias do período em questão para efeitos de análise intensiva: para a eleição de 1895 , a escolha recaiu sobre as datas de 19 e 24 de outubro e 5, 17 e 19 de novembro e, para a de 1906, sobre as datas de $16,17,19,20$ e 21 de agosto.

\subsubsection{As eleições de 1895 segundo $O$ Comércio do Porto e $A$ Voz Pública}

Inicio a abordagem ao ato eleitoral de 17 de novembro de 1895 pela ótica estatística.

Observemos a Tabela 2:

Tabela 2 - Número total de notícias publicadas sobre as Eleições Legislativas de 1895 no Porto na imprensa

\begin{tabular}{|c|c|}
\hline Jornal & N. $^{\text {o }}$ total de notícias/artigos de opinião sobre as eleições \\
\hline O Comércio do Porto & 5 \\
\hline A Voz Pública & 12 \\
\hline
\end{tabular}

FONTES: $O$ Comércio do Porto. Porto, 19 e 24 de outubro - 5, 17 e 19 de novembro de 1895; A Voz Pública. Porto, 19 e 24 de outubro - 5 , 17 e 19 de novembro de 1895 .

Nos cinco dias selecionados para análise intensiva, contando o número total de notícias/artigos de opinião publicados sobre o ato eleitoral de 1895 no Porto, percebe-se que $A$ Voz Pública publicou mais do dobro das notícias do que O Comércio do Porto (12 notícias/artigos contra 5).

Observemos, agora, a Tabela 3:

Tabela 3 - Número total de notícias publicadas sobre os monárquicos e os republicanos no âmbito da cobertura noticiosa sobre as Eleições Legislativas de 1895 no Porto na imprensa

\begin{tabular}{|c|c|c|}
\hline Jornal & $\begin{array}{c}\text { Total de notícias/artigos - } \\
\text { Monárquicos }\end{array}$ & $\begin{array}{c}\text { Total de notícias/artigos - } \\
\text { republicanos }\end{array}$ \\
\hline O Comércio do Porto & 5 & 0 \\
\hline A Voz Pública & 9 & 3 \\
\hline
\end{tabular}

FONTE: O Comércio do Porto. Porto, 19 e 24 de outubro - 5, 17 e 19 de novembro de 1895; A Voz Pública. Porto, 19 e 24 de outubro - 5, 17 e 19 de novembro de 1895 . 
Nos cinco dias selecionados para análise intensiva, contando o número total de notícias/ artigos de opinião publicados sobre monárquicos e republicanos no âmbito da cobertura noticiosa sobre as Eleições Legislativas de 1895 no Porto, percebe-se que: A Voz Pública escreveu mais sobre os monárquicos do que sobre os republicanos (9 notícias/artigos de opinião sobre os monárquicos contra 3 sobre os republicanos) e a explicação para o facto de $A$ Voz Pública dar tão pouca atenção aos republicanos nestas eleições residirá, parece-me, na informação que José Adelino Maltez divulgou na sua página profissional na internet ${ }^{24}$ que dá conta de que o Partido Progressista não concorreu em muitos círculos eleitorais e de que nos poucos em que o fez, fêlo em coligação com (estruturas locais do) Partido Republicano Português, parecendo-me plausível que tal situação (não consensual entre os republicanos e cujo diretório do partido terá imposto a abstenção nessas eleições) talvez provocasse embaraço ao jornal $A$ Voz Pública que, por via de uma cobertura menos extensa da campanha republicana, terá tentado desviar as atenções desta coligação. Já $O$ Comércio do Porto escreveu somente sobre os monárquicos (5 notícias/artigos de opinião), porventura por questões de afinidade politico-ideológica.

A análise do conteúdo das edições selecionadas para o efeito revela informações não só sobre a cobertura feita pelos dois jornais às "campanhas eleitorais" de 1895 e 1906 mas também sobre a forma como as mesmas decorreram.

Assim, no dia 19 de outubro de 1895, o jornal O Comércio do Porto não publicou qualquer notícia sobre as eleições nesta data e o jornal $A$ Voz Pública, na sua edição n ${ }^{\circ} 1699$, referiu na sua manchete uma notícia («Eleição de Deputados») na qual divulgava a informação de que alguém de Vila do Conde tinha como certa a sua nomeação como candidato do partido então no Poder pelo distrito do Porto a deputado à Câmara dos Deputados. Cerca de uma semana mais tarde, a 24 de outubro, o jornal $O$ Comércio do Porto não publicou qualquer notícia sobre as eleições e o jornal $A$ Voz Pública, na sua edição ${ }^{\circ} 1704$, referiu na sua manchete uma notícia («Candidato Clerical») na qual divulgava a informação de que os párocos de Penafiel estavam em negociações entre si para escolherem um deles como membro a ser nomeado deputado pelo governo de então nas legislativas de 17 de novembro, afirmando também que tudo não passava de mais um exemplo de como o governo se preparava para manipular os resultados eleitorais.

Já no dia 5 de novembro de 1895, o jornal O Comércio do Porto, na sua edição nº 263 , referiu na sua manchete um artigo de opinião («Revista Política») no qual se refletia, entre outros assuntos, sobre o estado da política portuguesa um ano antes das eleições de 17 de

\footnotetext{
${ }^{24}$ Maltez, José Adelino - Eleições de 1895. Maltez [Em linha]. [s.1]: Maltez, 2007. [s.num.].
} 
novembro de 1895 e sobre a sua evolução até à data da realização das mesmas. No caso do jornal $A$ Voz Pública, na sua edição n ${ }^{\circ} 1714$, da mesma data, publicou na sua manchete um artigo de opinião («Eleições») no qual se refletia sobre a grande dificuldade que o ministro do Reino, João Franco, estava a sentir para conseguir que os seus convites para a nomeação de deputados fossem aceites, dado ter recebido inúmeras recusas. ${ }^{25}$ Publicou-se (à semelhança do que fez O Comércio do Porto), também na manchete, uma notícia («Deputados pelo distrito do Porto») que dava conta da lista já concluída de deputados que haveriam de ser nomeados pelo distrito do Porto e que, de acordo com o jornal, fora elaborada pelo ministro do reino, João Franco.

No dia 17 de novembro de 1895, o jornal O Comércio do Porto, na sua edição $\mathrm{n}^{\circ} 274$, publicou na sua manchete uma notícia («Assembleias eleitorais») na qual se divulgavam os nomes dos representantes da autoridade nas assembleias eleitorais do Bairro Ocidental da cidade do Porto. Só no dia das eleições é que esta lista ficou definitivamente fechada. Já o jornal A Voz Pública, na sua edição ${ }^{\circ}$ 1725, publicou na sua manchete uma notícia («Substituição») na qual se divulgava a substituição, por motivos de saúde, do presidente da assembleia eleitoral de Santa Marinha (concelho de Vila Nova de Gaia).

No dia 19 de novembro de 1895 , o jornal $O$ Comércio do Porto, na sua edição no 275 , publicou uma notícia («Eleições de deputados») que dava conta dos resultados eleitorais destas legislativas em alguns concelhos do distrito do Porto (círculo eleitoral $\mathrm{n}^{\circ} 6$ ), ficando a faltar os concelhos de Vila Nova de Gaia, Lousada, Maia e Gondomar.

Tabela 4 - Resultados em alguns concelhos do círculo eleitoral no 6 (Porto Ocidental)

\begin{tabular}{|c|c|c|}
\hline \multicolumn{3}{|c|}{ Círculo Eleitoral no 6 (Porto Ocidental) } \\
\hline Concelhos & Regeneradores & Católicos \\
\hline Penafiel & 1206 & 602 \\
\hline Bouças & 1094 & 123 \\
\hline Paredes & 1322 & 98 \\
\hline Vila do Conde & 1311 & 247 \\
\hline Póvoa de Varzim & 1770 & 530 \\
\hline Felgueiras & 1330 & 487 \\
\hline Valongo & 1103 & 331 \\
\hline Baião & 1010 & 235 \\
\hline Amarante & 1273 & - \\
\hline Paços de Ferreira & 714 & 498 \\
\hline Santo Tirso & 1369 & 410 \\
\hline Marco de Canaveses & 1928 & $\mathbf{3 5 6 1}$ \\
\hline TOTAL & $\mathbf{1 5 4 3 0}$ & \\
\hline FONTE: $O$ Comércio do Porto Porto, 19/11/1895. & \\
\hline
\end{tabular}

FONTE: O Comércio do Porto. Porto, 19/11/1895.

\footnotetext{
25 “Eleições”. A Voz Pública. Porto, 05/11/1895, p. 1.
} 
O Comércio do Porto de 19 de novembro de 1895 publicou uma notícia («Gondomar, 18 de novembro») que dava conta dos resultados eleitorais destas legislativas no concelho de Gondomar (círculo eleitoral $\mathrm{n}^{\circ}$ 6) que ainda não eram conhecidos na outra notícia do mesmo dia. Deste modo, foi levado ao conhecimento do público que em Gondomar "a lista governamental obteve aqui (S. Cosme) e em todo o concelho 587 votos e os católicos 298. Não houve ocorrência digna de mencionar-se. - (Do nosso corresp.)." ${ }^{26}$ Adicionalmente (na mesma coluna) pode encontrar-se a informação de que em outros concelhos do mesmo círculo eleitoral a votação decorreu da seguinte forma, como observável na Tabela 5 (da mesma edição de 19 de novembro de 1895):

Tabela 5 - Resultados eleitorais nos concelhos de Baião (neste concelho a oposição não foi às urnas), Santo Tirso e Marco de Canaveses

\begin{tabular}{|c|c|c|c|}
\hline Candidato & Baião & Santo Tirso & Marco de Canaveses \\
\hline Campos Henriques & 1027 & 1369 & 2048 \\
\hline Barbosa de Mendonça & \multirow{11}{*}{942} & 1279 & 1954 \\
\hline Veloso da Cruz & & 1279 & 1928 \\
\hline Morais Carvalho & & 1126 & 1928 \\
\hline Augusto Gama & & 1129 & 1928 \\
\hline Diogo Cabral & & 1369 & 1804 \\
\hline Teixeira de Vasconcelos & & 1299 & 2002 \\
\hline Lopes Coelho & & 1299 & 2002 \\
\hline Pinto Leite & & 1199 & 1897 \\
\hline Manuel Guedes & & 1299 & 2016 \\
\hline Sousa Avides & & 1299 & 1952 \\
\hline Wenceslau de Lima & & 1299 & 1900 \\
\hline Sena Freitas & \multirow{3}{*}{235} & 500 & 410 \\
\hline José de Saldanha & & 500 & 410 \\
\hline D. Tomás de Almeida & & 500 & 410 \\
\hline
\end{tabular}

O jornal A Voz Pública, na sua edição no 1726, de 19 de novembro de 1895, publicou na sua manchete um artigo de opinião («Epílogo») no qual se produzia uma crítica ao ato eleitoral realizado dois dias antes e ao sistema político como um todo.

De qualquer modo, e para terminar este ponto, cumpre-me fazer uma ressalva: as edições consultadas de ambos os jornais não permitem conhecer a globalidade dos resultados no Porto (na cidade e no distrito), mas foi o Partido Regenerador a vencer as eleições no reino.

\footnotetext{
26 “Gondomar, 18 de novembro". O Comércio do Porto. Porto, 19/11/1895, p. 3.
} 


\subsubsection{As eleições de 1906 segundo $O$ Comércio do Porto e $A$ Voz Pública}

À semelhança do que sucedeu no ponto 3.1.1., iniciarei uma abordagem estatística ao ato eleitoral de 19 de agosto de 1906.

Observemos a Tabela 6:

Tabela 6 - Número total de notícias publicadas sobre as Eleições Legislativas de 1906 no Porto na imprensa

\begin{tabular}{|c|c|}
\hline Jornal & N. $^{\text {o }}$ total de notícias/artigos de opinião sobre as eleições \\
\hline O Comércio do Porto & 11 \\
\hline A Voz Pública & 13 \\
\hline
\end{tabular}

FONTE: O Comércio do Porto. Porto, 16, 17, 19, 20 e 21 de agosto de 1906; A Voz Pública. Porto, 16, 17, 19, 20 e 21 de agosto de 1906.

Nos cinco dias selecionados para análise intensiva, contando o número total de notícias/artigos de opinião publicados sobre o ato eleitoral de 1906 no Porto, percebe-se que $A$ Voz Pública publicou apenas mais duas notícias/artigos de opinião do que O Comércio do Porto (13 notícias contra 11), verificando-se assim um maior equilíbrio numérico entre ambos os jornais face ao apurado para 1895. No caso concreto de $O$ Comércio do Porto, este periódico até publicou em 1906 mais do dobro das notícias/artigos que publicou em 1895. Talvez o maior número de notícias publicadas por A Voz Pública relativamente ao tema das eleições de 1895 e 1906 face ao publicado por $O$ Comércio do Porto (monárquico) esteja relacionado com a dinâmica da ação contestatária face ao regime monárquico e propagandística das virtudes do republicanismo que caracterizava este jornal da esquerda republicana.

Observemos a Tabela 7: ${ }^{27}$

Tabela 7 - Número total de notícias publicadas sobre os monárquicos e os republicanos no âmbito da cobertura noticiosa sobre as Eleições Legislativas de 1906 no Porto na imprensa

\begin{tabular}{|c|c|c|}
\hline Jornal & $\begin{array}{c}\text { N. }{ }^{\mathbf{o}} \text { total de notícias/artigos - } \\
\text { Monárquicos }\end{array}$ & N. ${ }^{\mathbf{0}}$ total de Notícias/artigos - republicanos \\
\hline O Comércio do Porto & 8,5 & 2,5 \\
\hline A Voz Pública. & 3,5 & 9,5 \\
\hline
\end{tabular}

FONTE: O Comércio do Porto. Porto, 16, 17, 19, 20 e 21 de agosto de 1906; A Voz Pública. Porto, 16, 17, 19, 20 e 21 de agosto de 1906.

Nos cinco dias selecionados para análise intensiva, contando o número total de notícias/artigos de opinião publicados sobre os monárquicos e sobre os republicanos no âmbito da cobertura noticiosa sobre as eleições legislativas de 1906 no Porto, percebe-se que: a) $A$ Voz Pública publicou maior número de notícias/artigos de opinião sobre os republicanos do que

\footnotetext{
${ }^{27}$ As notícias relativas diretamente a resultados e procedimentos eleitorais sendo alusivas tanto a monárquicos como a republicanos levaram-me a, perante cada uma dessas notícias, atribuir metade da notícia aos monárquicos e a outra metade aos republicanos (daí se observar na Tabela 9 valores como " 8,5 ", "2,5", "3,5" e "9,5").
} 
sobre os monárquicos (9,5 notícias/artigos contra 3,5), b) O Comércio do Porto publicou (ao contrário de $A$ Voz Pública) um maior número de notícias/artigos de opinião sobre os monárquicos do que sobre os republicanos (8,5 notícias/artigos contra 2,5), c) A Voz Pública inverteu (em 1906), em termos de número de notícias publicadas sobre monárquicos e republicanos, a tendência verificada nas edições selecionadas de 1895, d) O Comércio do Porto manteve (em 1906), em termos de número de notícias publicadas sobre monárquicos e republicanos a mesma tendência de 1895 sendo que, neste último ano, nem sequer escreveu sobre os republicanos.

No dia 16 de agosto de 1906, o jornal O Comércio do Porto, na sua edição no 193 , publicou na manchete uma notícia («Os candidatos a deputados pelo Porto») na qual se divulgava a lista de candidatos a deputados pelo distrito do Porto por partidos políticos. Os seus nomes poderão ser consultados na tabela abaixo:

Tabela 8 - Candidatos a deputados pelo distrito do Porto

\begin{tabular}{|c|c|c|}
\hline \multicolumn{3}{|c|}{ Círculo Oriental (n⿳05) } \\
\hline $\begin{array}{l}\text { Concentração Liberal } \\
\text { (Governamentais) }\end{array}$ & $\begin{array}{l}\text { Regeneradores } \\
\text { (Oposição) }\end{array}$ & $\begin{array}{l}\text { Republicanos } \\
\text { (Oposição) }\end{array}$ \\
\hline $\begin{array}{l}\text { José de Abreu do Couto de Amorim } \\
\text { Novais }\end{array}$ & $\begin{array}{c}\text { Alberto de Castro Pereira de } \\
\text { Almeida Navarro }\end{array}$ & António Luís Gomes \\
\hline José da Cunha Rola & Clemente Joaquim dos Santos Pinto & Antão Fernandes de Carvalho \\
\hline D. Luís Pizarro Cunha Portocarrero & Manuel de Sousa Avides & $\begin{array}{c}\text { António Augusto Cerqueira } \\
\text { Coimbra }\end{array}$ \\
\hline Paulo de Barros Pinto Osório & José Fernando de Sousa & Francisco Xavier Esteves \\
\hline Luís Vaz de Carvalho Crespo & Francisco Joaquim Fernandes & Teófilo Braga \\
\hline \multicolumn{3}{|c|}{ Círculo Ocidental (nº) } \\
\hline $\begin{array}{l}\text { Concentração Liberal } \\
\text { (Governamentais) }\end{array}$ & $\begin{array}{l}\text { Regeneradores } \\
\text { (Oposição) }\end{array}$ & $\begin{array}{l}\text { Republicanos } \\
\text { (Oposição) }\end{array}$ \\
\hline Henrique Carlos de Carvalho Kendall & Conde de Paçô Vieira & Abílio Guerra Junqueiro \\
\hline Adriano Antero de Sousa Pinto & Conde de Castro Solla & Manoel Augusto Alves da Veiga \\
\hline José Domingues de Oliveira & $\begin{array}{l}\text { José António Alves Ferreira de } \\
\text { Lemos Júnior }\end{array}$ & António Francisco Coelho \\
\hline Alfredo Ferreira de Matos & José Joaquim Mendes Leal & João José de Freitas \\
\hline Artur Eduardo de Almeida Brandão & João Pinto Rodrigues dos Santos & José Nunes da Ponte \\
\hline
\end{tabular}

FONTE: O Comércio do Porto. Porto, 16/08/1906, edição nº 193.

O jornal $A$ Voz Pública, na sua edição n ${ }^{0}$ 5051, publicou (tal como O Comércio do Porto) uma notícia («Candidatos Republicanos») na qual se divulgavam os nomes dos candidatos do PRP no Porto - Bairro Oriental (círculo n. ${ }^{\circ}$ 5) e Porto - Bairro Ocidental (círculo n. ${ }^{\circ}$ 6). $\mathrm{Na}$ manchete há uma notícia («Propaganda Republicana - Os comícios de ontem») na qual se alude ao modo como correram os comícios da véspera. 
No dia 17 de agosto de 1906, o jornal O Comércio do Porto, na sua edição nº 194 , publicou uma notícia («Centro Regenerador-Liberal») na qual se podia ler a lista de candidatos a deputados pela cidade do Porto pela Concentração Liberal (Partido Regenerador-Liberal + Partido Progressista).

O jornal $A$ Voz Pública, na sua edição $n^{\circ}$ 5052, publicou na manchete uma notícia («Propaganda Republicana em Cedofeita e Vitória e em Vila Nova de Gaia») na qual se anunciava a realização de conferências republicanas em Cedofeita, em Vitória e em Vila Nova de Gaia para efeitos de propaganda.

No dia 19 de agosto de 1906, o jornal O Comércio do Porto, na sua edição nº 196, publicou na manchete uma notícia («As eleições forças militares») na qual se anunciava que seriam enviadas forças militares para vigiar determinadas assembleias eleitorais em diversos concelhos do distrito eleitoral do Porto. Ainda na primeira página do jornal surgia a notícia «Eleição de Deputados» que informava os leitores sobre os nomes das pessoas que iriam representar a autoridade nas assembleias eleitorais do concelho de Vila Nova de Gaia.

O jornal A Voz Pública, na sua edição n ${ }^{0} 5054$, da mesma data, publicou na manchete uma notícia («Representantes do Partido Republicano nas Assembleias Eleitorais») em que era divulgada a lista dos representantes do Partido Republicano Português nas Assembleias Eleitorais.

No dia 20 de agosto de 1906, o jornal O Comércio do Porto, no suplemento ao número 196 de 19 de agosto, publicou um artigo intitulado «Eleições» no qual era produzida uma crítica à lei eleitoral em vigor à data das eleições legislativas da véspera (o decreto de 4 de agosto de 1901). Surge, igualmente na primeira página, uma notícia intitulada «A Eleição no Porto» que consistia numa descrição da forma como decorrera o ato eleitoral na cidade do Porto (referência a pequenos incidentes nas assembleias eleitorais como, por exemplo, a ação dos marcas, ou seja, pessoas que votavam, fraudulentamente, por outro(s) indivíduo(s), aos primeiros resultados da eleição e a considerações de outra ordem):

$\mathrm{O}$ ato eleitoral decorreu com regularidade no Porto, aparte incidentes que sempre se dão nestas ocasiões, ficando assim, por completo, demonstrada a inanidade da concentração da força pública. Os diversos partidos em luta tiveram representação nas mesas das assembleias eleitorais, como já acontecera na penúltima eleição de 29 de abril do corrente ano. [...]

$\mathrm{O}$ apuramento concluiu em todas as assembleias, exceto nas dos Congregados e de Paranhos. Todavia, o apuramento pendente pouco pode influir no resultado geral da votação. [...]

Houve diversos incidentes, no fundo sem importância de maior. [...]

Em Massarelos houve ligeiras altercações, devido isso a eleitores recenseados em outras freguesias desejarem votar ali. Foi preso o trabalhador António Pascoal Ximenes e levado para a 7. ${ }^{\mathrm{a}}$ esquadra policial, por se apurar que, depois de ter votado, tentava votar novamente por um indivíduo ausente. $[\ldots]^{28}$

\footnotetext{
28 “A Eleição no Porto”. O Comércio do Porto. Porto, 20/08/1906, p. 1.
} 
De seguida, na mesma edição, há que referir a notícia «Os outros Círculos» que informava de modo breve os leitores sobre a forma como o ato eleitoral decorrera em vários círculos mormente no norte de Portugal sendo que os resultados mais importantes para esta investigação são os dos círculos eleitorais n. ${ }^{\circ}$ s 5 (Porto Oriental) e 6 (Porto Ocidental). Neste suplemento ao número 196 de 19 de agosto foi fornecida aos leitores uma tabela (Tabela 9), intitulada «Círculo Oriental e Círculo Ocidental», representativa dos resultados eleitorais nos bairros oriental e ocidental da cidade do Porto e que abaixo se expõe:

Tabela 9 - Resultados do sufrágio de agosto de 1906 nos bairros oriental e ocidental da cidade

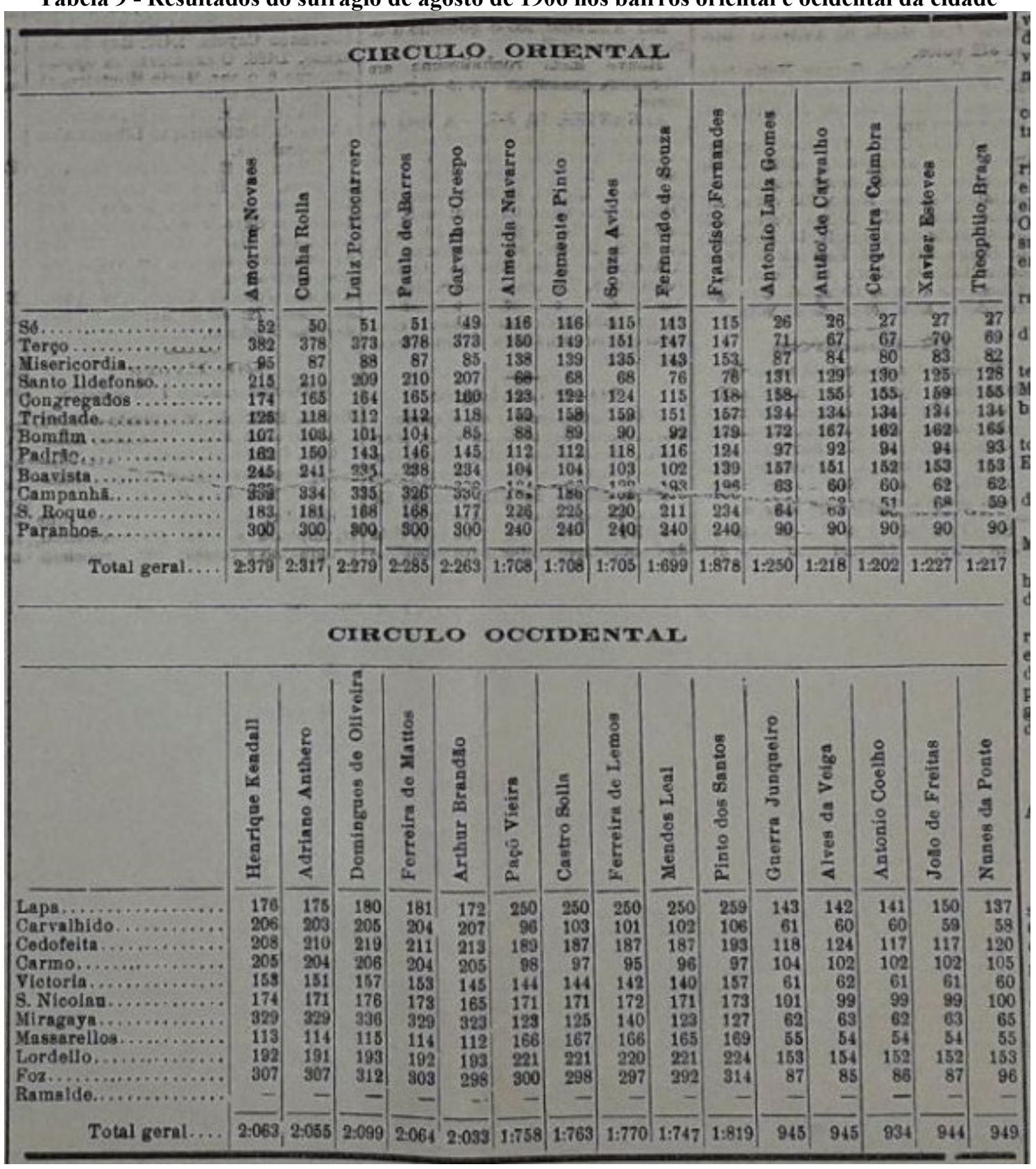

FONTE: O Comércio do Porto. Porto, 20/08/1906. 
Já o jornal $A$ Voz Pública, no suplemento (com data de 20 de agosto) à edição $\mathrm{n}^{0} 5054$ de 19 de agosto, na primeira página, também fornecia aos leitores uma tabela intitulada «Eleições» com os resultados do sufrágio divididos pelos bairros oriental e ocidental da cidade e os nomes dos candidatos envolvidos e agrupados por fação política conforme se poderá verificar na Tabela 10:

Tabela 10 - Resultados do sufrágio de agosto de 1906 nos bairros oriental e ocidental da cidade

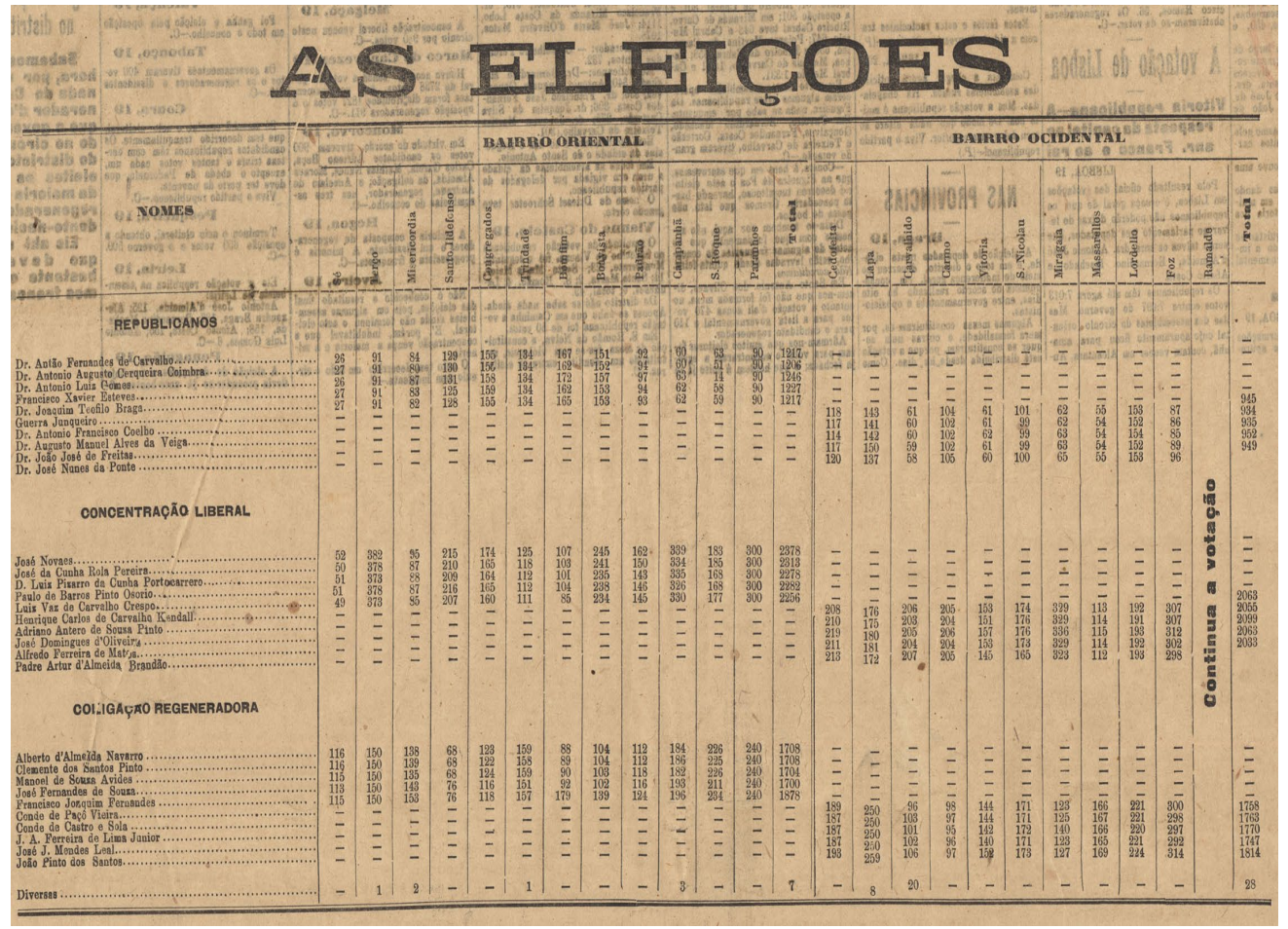

FONTE: A Voz Pública. Porto, 20/08/1906.

Ainda neste suplemento surge: um artigo de opinião alusivo aos resultados eleitorais no Porto, com o título «Viva a República»; também na primeira página surge uma notícia em que se estabelece uma comparação entre os resultados da eleição de 29 de abril de 1906 com a de 19 de agosto do mesmo ano no Porto, com o título «Votação Anterior»; ainda na mesma página é feito um relato sobre a forma como decorreram as votações em várias assembleias de voto da cidade do Porto, sob o título «No Porto» ${ }^{29}$, sendo possível recolher informações sobre a ocorrência de incidentes durante o ato eleitoral em determinadas assembleias de voto que não foram referidas anteriormente como sejam as dos Congregados, da Lapa, de Cedofeita e de Lordelo.

Já na segunda página do suplemento de 20 de agosto, surge uma notícia em que são divulgados os resultados eleitorais em Amarante, Lousada, Santo Tirso e Marco de Canaveses, sob o título «Nas províncias»; finalmente (e também na mesma página), uma notícia que dava

\footnotetext{
29 "No Porto". A Voz Pública. Porto, 20/08/1906, p. 1
} 
conta de que o Governo tinha perdido a eleição no círculo ocidental do distrito, sob o título «O Governo perde um círculo no distrito do Porto». Eis o que nos diz ipsis verbis o texto noticioso:

O governo perde um círculo no distrito do Porto.

Sabemos à última hora, por notícia emanada do Centro Regenerador desta cidade, que o governo foi batido no círculo ocidental do distrito, estando eleitos os candidatos da maioria da coligação regeneradora-dissidente-nacionalista.

Eis aí uma notícia que deve arrefecer bastante os entusiasmos francáceos..$^{30}$

No dia 21 de agosto de 1906, o jornal O Comércio do Porto, publicou na manchete uma notícia («Os novos deputados») na qual foi dado destaque aos nomes dos deputados eleitos pelos dois círculos (5 e 6) do Porto com uma lista dividida por círculos eleitorais a nível nacional com os nomes dos deputados eleitos e os partidos a que pertenciam, terminando com a composição provisória da nova Câmara dos Deputados, partido a partido. Observe-se as três tabelas seguintes $(11,12$ e 13), extraídas da referida notícia:

Tabela 11 - Candidatos a deputados eleitos pelo círculo oriental (n5) do Porto

\begin{tabular}{|c|c|c|c|}
\hline \multicolumn{4}{|c|}{ Círculo Oriental (n'5) } \\
\hline Partido Regenerador-Liberal & Partido Progressista & Partido Regenerador & Dissidência \\
\hline $\begin{array}{c}\text { José de Abreu do Couto Pinto de } \\
\text { Amorim Novais (Ministro da } \\
\text { Justiça do Governo em funções) }\end{array}$ & $\begin{array}{c}\text { Paulo de Barros Pinto } \\
\text { Osório }\end{array}$ & Clemente Joaquim dos \\
Santos Pinto & Francisco \\
\hline José da Cunha Rola Pereira & Luís Vaz de Carvalho & & Fernandes \\
\hline D. Luís Pizarro da Cunha & Crespo & & \\
Portocarrero & & & \\
\hline
\end{tabular}

FONTE: O Comércio do Porto. Porto, 21/08/1906.

Tabela 12 - Candidatos a deputados eleitos pelo círculo ocidental (nº) do Porto

\begin{tabular}{|c|c|c|c|}
\hline \multicolumn{2}{|c|}{ Círculo Ocidental (no6) } \\
\hline $\begin{array}{c}\text { Partido Regenerador- } \\
\text { Liberal }\end{array}$ & Partido Progressista & Partido Regenerador & Dissidência \\
\hline $\begin{array}{c}\text { José Domingues de } \\
\text { Oliveira }\end{array}$ & $\begin{array}{c}\text { Henrique Carlos de } \\
\text { Carvalho Kendall }\end{array}$ & Conde de Castro Solla & $\begin{array}{c}\text { João Pinto Rodrigues dos } \\
\text { Santos }\end{array}$ \\
\hline $\begin{array}{c}\text { Alfredo Ferreira de } \\
\text { Matos }\end{array}$ & Conde de Paçô Vieira & \\
\hline $\begin{array}{c}\text { Artur Eduardo de } \\
\text { Almeida Brandão }\end{array}$ & & & \\
\hline
\end{tabular}

FONTE: O Comércio do Porto. Porto, 21/08/1906.

\footnotetext{
${ }^{30}$ A Voz Pública. Porto, 20/08/1906, p. 2.
} 
O Comércio do Porto deu, na notícia acima referida, como eleitos estes candidatos a deputados pelos dois círculos do Porto ainda que a contagem dos votos não estivesse completa: "O resultado da eleição nos dois círculos do Porto depende ainda da adjunção dos apuramentos nas assembleias dos 16 concelhos deste distrito. Todavia, os que tem mais probabilidades de ficar eleitos são os cavalheiros indicados." 31

Seguem-se os resultados então provisórios avançados por $O$ Comércio do Porto com a vitória a nível nacional da Concentração Liberal (Partido Regenerador-Liberal em coligação com o Partido Progressista):

Tabela 13 - Composição provisória da nova Câmara dos Deputados saída das eleições de 19 de agosto de 1906

\begin{tabular}{|c|c|}
\hline Partidos Políticos & N. ${ }^{\mathbf{0}}$ de deputados eleitos \\
\hline Regeneradores-liberais & 67 \\
\hline Progressistas & 42 \\
\hline Regeneradores & 27 \\
\hline Republicanos & 4 \\
\hline Nacionalistas & 4 \\
\hline Dissidentes & 3 \\
\hline Independentes & $\mathbf{1 4 8}$ \\
\hline TOTAL & \\
\hline
\end{tabular}

FONTE: O Comércio do Porto. Porto, 21/08/1906.

Na mesma edição, surge outra notícia («Eleições») na qual foram divulgados os resultados eleitorais em falta no dia anterior (20 de agosto) relativos à cidade do Porto, mais concretamente às assembleias eleitorais dos Congregados e de Paranhos (ambas do Bairro Oriental) e Ramalde (do Bairro Ocidental), bem como dos nomes dos deputados eleitos por cada um destes dois bairros e respetivas votações (as votações dos Congregados e de Paranhos aparecem diluídas na votação total do seu bairro) e com a divulgação, também, de informações relativas a incidentes ocorridos nestas assembleias durante as votações. Há, além disso, na mesma notícia informações relativas a outros círculos eleitorais que não os do Porto mas essas não têm interesse para este trabalho. Na terceira página, surge a notícia «As eleições no Porto» relativa a um telegrama que o chefe do governo à data (João Franco) recebeu da parte da Câmara Municipal do Porto relatando episódios de violência em determinadas assembleias eleitorais e solicitando a tomada de medidas no sentido de impedir a repetição destes episódios em futuros atos eleitorais.

\footnotetext{
${ }^{31}$ O Comércio do Porto. Porto, 21/08/1906.
} 
O jornal $A$ Voz Pública, na sua edição ${ }^{\circ} 5055$, publicou: na primeira página, uma notícia com a informação de que os republicanos haviam conseguido eleger quatro deputados em Lisboa e que o Partido Republicano Português havia mantido a sua votação no Porto, sob o título «A vitória republicana - avante pela República»; ainda na primeira página, uma notícia em que foi divulgado o envio de diversos telegramas por parte de várias entidades do Porto a fim de saudarem os quatros deputados republicanos de Lisboa pela sua recente eleição para o parlamento, sob o título «Saudações - Os deputados republicanos de Lisboa»; na segunda página, uma notícia relativa aos resultados eleitorais em vários outros pontos da cidade e em certas províncias, sob o título «As eleições - as votações da cidade».

Terminada esta viagem pela campanha eleitoral das eleições legislativas de 1906 no Porto, através das páginas de $O$ Comércio do Porto e de $A$ Voz Pública, chegou o momento de apresentar (com base nas informações recolhidas a partir destes dois periódicos) os resultados eleitorais mais atualizados (uma vez que se encontram dispersos por diferentes edições). Nas tabelas 14 e $15^{32}$ é possível observar os resultados nos dois bairros eleitorais da cidade do Porto:

Tabela 14 - Resultados eleitorais no Bairro Oriental da cidade do Porto

\begin{tabular}{|c|c|c|c|c|c|c|c|c|c|}
\hline \multicolumn{2}{|c|}{ Reg.-liberais } & \multicolumn{2}{|c|}{ Progressistas } & \multicolumn{2}{|c|}{ Regeneradores } & \multicolumn{2}{|c|}{ Dissidentes } & \multicolumn{2}{|c|}{ Republicanos } \\
\hline Candidato & Vot. & Candidato & Vot. & Candidato & Vot. & Candidato & Vot. & Candidato & Vot. \\
\hline $\begin{array}{l}\text { Amorim } \\
\text { Novais }\end{array}$ & 2436 & $\begin{array}{l}\text { Paulo de } \\
\text { Barros }\end{array}$ & 2338 & $\begin{array}{l}\text { Almeida } \\
\text { Navarro }\end{array}$ & 1775 & $\begin{array}{l}\text { Francisco } \\
\text { Fernandes }\end{array}$ & 1949 & $\begin{array}{l}\text { A. Luís } \\
\text { Gomes }\end{array}$ & 1277 \\
\hline Cunha Rola & 2370 & $\begin{array}{c}\text { Carvalho } \\
\text { Crespo }\end{array}$ & 2313 & $\begin{array}{c}\text { Clemente } \\
\text { Pinto }\end{array}$ & 1776 & & & $\begin{array}{l}\text { Antão de } \\
\text { Carvalho }\end{array}$ & 1245 \\
\hline $\begin{array}{c}\text { Luís } \\
\text { Portocarrero }\end{array}$ & 2332 & & & $\begin{array}{c}\text { Sousa } \\
\text { Avides }\end{array}$ & 1773 & & & $\begin{array}{l}\text { Cerqueira } \\
\text { Coimbra }\end{array}$ & 1229 \\
\hline & & & & $\begin{array}{c}\text { Fernando de } \\
\text { Sousa }\end{array}$ & 1765 & & & $\begin{array}{l}\text { Xavier } \\
\text { Esteves }\end{array}$ & 1253 \\
\hline & & & & & & & & $\begin{array}{l}\text { Teófilo } \\
\text { Braga }\end{array}$ & 1244 \\
\hline TOTAL & 2379 & TOTAL & 2326 & TOTAL & 1772 & TOTAL & 1949 & TOTAL & 1250 \\
\hline
\end{tabular}

FONTE: $O$ Comércio do Porto. Porto, 20 e 21/08/1906.

\footnotetext{
${ }^{32}$ Os resultados de ambas as tabelas surgem da soma dos valores inscritos nas edições de 20 e 21 de agosto de 1906 de O Comércio do Porto. Dito de modo mais rigoroso, após o apuramento da votação individual de cada candidato de cada lista partidária em cada círculo, passou-se à fase seguinte: apurar a votação total de cada lista partidária em cada um dos círculos analisados nas tabelas 14 e 15 . Dado que as listas eram «abertas» e não «fechadas e bloqueadas» (o que significa que cada eleitor votava numa lista, podendo eliminar ou substituir alguns dos nomes que figuravam nos boletins de voto distribuídos pelos partidos concorrentes), a votação de cada lista partidária corresponde à média dos votos recebidos pelos nomes que a compõem.
} 
Tabela 15 - Resultados eleitorais no Bairro Ocidental da cidade do Porto

\begin{tabular}{|c|c|c|c|c|c|}
\hline \multicolumn{2}{|c|}{ Concentração Liberal } & \multicolumn{2}{|c|}{ Regeneradores } & \multicolumn{2}{|c|}{ Republicanos } \\
\hline Candidato & Vot. & Candidato & Vot. & Candidato & Vot. \\
\hline $\begin{array}{l}\text { Henrique Carlos de Carvalho } \\
\text { Kendall }\end{array}$ & 2286 & $\begin{array}{c}\text { Conde de Paçô } \\
\text { Vieira }\end{array}$ & 1927 & $\begin{array}{l}\text { A. Guerra } \\
\text { Junqueiro }\end{array}$ & 978 \\
\hline Adriano Antero de Sousa Pinto & 2278 & $\begin{array}{c}\text { Conde de Castro } \\
\text { Solla }\end{array}$ & 1931 & $\begin{array}{c}\text { Augusto M. } \\
\text { Alves da Veiga }\end{array}$ & 978 \\
\hline José Domingues de Oliveira & 2321 & $\begin{array}{l}\text { José A. A. } \\
\text { Ferreira de } \\
\text { Lemos J. }\end{array}$ & 1939 & $\begin{array}{l}\text { A. Francisco } \\
\text { Coelho }\end{array}$ & 967 \\
\hline Alfredo Ferreira de Matos & 2287 & $\begin{array}{c}\text { José J. Mendes } \\
\text { Leal }\end{array}$ & 1914 & $\begin{array}{c}\text { João José de } \\
\text { Freitas }\end{array}$ & 977 \\
\hline $\begin{array}{l}\text { Artur Eduardo de Almeida } \\
\text { Brandão }\end{array}$ & 2255 & $\begin{array}{c}\text { João P. R. } \\
\text { Santos }\end{array}$ & 1986 & $\begin{array}{l}\text { José Nunes da } \\
\text { Ponte }\end{array}$ & 981 \\
\hline TOTAL & 2285 & TOTAL & 1939 & TOTAL & 976 \\
\hline
\end{tabular}

FONTE: O Comércio do Porto. Porto, 20 e 21/08/1906.

Observemos, agora, os resultados eleitorais para os dois círculos em que se dividia o distrito do Porto em 1906. Na Tabela 16, encontramos os elementos relativos ao Círculo Oriental:

Tabela 16 - Resultados no Círculo Oriental (n5) do distrito eleitoral do Porto ${ }^{33}$

\begin{tabular}{|c|c|c|c|c|c|}
\hline \multicolumn{2}{|c|}{ Concentração Liberal } & \multicolumn{2}{|c|}{ Regeneradores } & \multicolumn{2}{|c|}{ Republicanos } \\
\hline Candidato & Vot. & Candidato & Vot. & Candidato & Vot. \\
\hline José Novais & 8280 & Alberto Navarro & 6448 & Antão de Carvalho & 1245 \\
\hline Rola Pereira & 8214 & Clemente Pinto & 6450 & Cerqueira Coimbra & 1234 \\
\hline Luís Portocarrero & 8176 & Sousa Avides & 6455 & A. Luís Gomes & 1277 \\
\hline Paulo de Barros & 8182 & Fernando de Sousa & 6439 & Xavier Esteves & 1255 \\
\hline Carvalho Crespo & 8153 & $\begin{array}{c}\text { Francisco Joaquim } \\
\text { Fernandes }\end{array}$ & 6623 & Teófilo Braga & 1243 \\
\hline TOTAL & 8201 & TOTAL & 6483 & TOTAL & 1251 \\
\hline
\end{tabular}

FONTE: A Voz Pública. Porto, 22/08/1906.

A informação presente na tabela acima ${ }^{34}$ vem acompanhada de uma análise. $A V o z$ Pública afirma que:

Em face portanto destas votações, foram eleitos pela maioria no círculo n. ${ }^{\circ}$, os governamentais, srs. José Novais, Rola Pereira, Paulo de Barros, Luís Portocarrero e Carvalho Crespo. Pela minoria o regenerador dr. Sousa Avides, e o dissidente, dr. Francisco Joaquim Fernandes. No círculo n. ${ }^{\circ}$ 6, eleitos, pela maioria, os governamentais, srs. Dr. José

\footnotetext{
${ }^{33}$ A mesma explicação vale para a Tabela 16.

${ }^{34}$ A Voz Pública. Porto, 22/08/1906. Esta edição de A Voz Pública não faz parte das edições selecionadas para análise intensiva no âmbito deste trabalho. No entanto, dado o conteúdo desta notícia, pareceu-me útil incluí-la na presente investigação.
} 
Domingos de Oliveira, Carvalho Kendall, Almeida Brandão e Alfredo Matos e o dissidente, sr. João Pinto dos Santos. Pela minoria, os regederadores [sic] Ferreira de Lemos e Paçô Vieira. Fica portanto fora da câmara o governamental, dr. Adriano Antero. ${ }^{35}$

Em suma, consultando os jornais, foi possível saber quais as formações políticas mais votadas no Porto em agosto de 1906 no bairro oriental da cidade (a Concentração Liberal, composta pelos regeneradores-liberais e pelos progressistas, com $2379+2326=4705$ votos), no bairro ocidental da cidade (a Concentração Liberal com 2285 votos) e no círculo oriental $\left(n^{0} 5\right)$ do distrito do Porto (a Concentração Liberal com 8201 votos).

Em jeito de resumo da análise efetuada às edições de 1895 e 1906 dos dois jornais analisados no âmbito desta investigação, há que referir que talvez o maior número de notícias publicadas por $A$ Voz Pública relativamente ao tema das eleições de 1895 (sobretudo estas) e 1906 face ao publicado por $O$ Comércio do Porto (monárquico) esteja relacionado com a própria dinâmica da ação contestatária face ao regime monárquico português e propagandística das virtudes do republicanismo que caracterizava este jornal afeto à corrente da esquerda republicana. Penso que se percebe através da leitura destes dois jornais que, apesar de se encontrar críticas à política monárquica nas páginas de $O$ Comércio do Porto, este jornal assumiu, ainda assim, uma postura mais suave face ao regime político vigente do que $A$ Voz Pública.

De um modo genérico, as notícias sobre a política portuguesa estão concentradas na primeira página destes jornais, podendo estender-se, por vezes, à segunda e, excecionalmente, à terceira.

Relativamente aos temas mais recorrentes em ambos os jornais, há que referir a divulgação de listas de candidatos a deputados pelo círculo do Porto (O Comércio do Porto privilegiava as listas monárquicas e $A$ Voz Pública as republicanas) e as questões ligadas ao funcionamento das assembleias eleitorais do Porto (preparação para as eleições). Refira-se, ainda, a divulgação de ações partidárias de campanha eleitoral (O Comércio do Porto divulgava as do Centro Regenerador-Liberal em 1906 como, por exemplo, conferências e A Voz Pública as republicanas que consistiam, essencialmente, sobretudo a partir de 1901, em grandes comícios e jantares mais privados sendo que os notáveis locais eram convidados para esses jantares partidários na sequência de uma tentativa de atração das classes média e alta. Por outro lado, os republicanos confiavam que a adesão popular aconteceria naturalmente sem que houvesse necessidade de lhe prestar uma atenção especial) e a apresentação dos resultados nos dois círculos eleitorais do Porto.

Em relação às abordagens de ambos os jornais a ambas as eleições há que referir que, no que toca à cobertura das respetivas campanhas eleitorais, percebe-se que tanto $O$ Comércio

\footnotetext{
${ }^{35}$ Idem.
} 
do Porto como A Voz Pública forneceram informações muito mais vagas em 1895 do que em 1906. No caso particular de A Voz Pública, observa-se uma atitude muito mais aguerrida e interventiva nas edições de 1906 do que nas de 1895, sendo que nestas quase não publica notícias sobre o ato eleitoral (nos dias a seguir ao mesmo), limitando-se a breves e genéricas considerações sobre o mesmo sob a forma de editoriais. Em ambos os periódicos não é só a quantidade de informação veiculada que aumenta de uma eleição para a outra, sucedendo o mesmo com o grau de detalhe da informação, especialmente no que toca aos resultados eleitorais: em 1895 só são divulgados resultados parciais e para o círculo ocidental (n. ${ }^{\circ}$ 6) do Porto, faltando conhecer os dados de alguns concelhos; em 1906, já se consegue aceder aos dados relativos aos dois bairros administrativos da cidade, por um lado, e aos dois círculos do distrito, por outro (ficando-se com uma imagem global bastante mais nítida).

\section{Conclusão}

O contributo mais relevante do presente artigo é o que respeita à comparação da cobertura jornalística das eleições de 1895 e de agosto de 1906 pelos jornais O Comércio do Porto (monárquico) e $A$ Voz Pública (republicano) bem como à recolha e sistematização dos resultados eleitorais nos círculos do Porto.

A realização da presente investigação foi mostrando, ao longo do tempo, que há várias questões que, com mais tempo disponível para investigar e com recursos, poderiam ser abordadas de forma mais aprofundada. Refiro-me, por exemplo, à estrutura interna dos partidos políticos monárquicos e do Partido Republicano Português (estatutos, hierarquias, modo de funcionamento e pessoas responsáveis pelos centros políticos que serviam para difundir a propaganda partidária), às pessoas que impulsionavam as estruturas republicanas do Porto, às diferenças ideológicas entre os diversos partidos da monarquia e entre estes e o PRP, ao modo exato como funcionavam as assembleias eleitorais e até que ponto o cumprimento da lei eleitoral se verificava nas mesmas (e quem fiscalizava esse cumprimento). Considero que seria igualmente interessante perceber em pormenor quem eram os homens (percursos académico, político, profissional e familiar) que aceitaram candidatar-se a deputados pelo círculo do Porto em ambas as eleições legislativas pelos vários partidos políticos que concorreram a um lugar na Câmara dos Deputados, tudo com vista a tentar compreender o que os motivou a enveredar pela carreira política (dinheiro? Estatuto social? Dedicação genuína à causa pública? Vontade de afirmação pessoal?).

De qualquer modo, foi possível através das fontes, tanto de $A$ Voz Pública como de $O$ Comércio do Porto, saber um pouco mais sobre a história das eleições de deputados de 1895 e 
de 1906, tal como elas foram vividas no Porto, quer cidade quer enquanto círculo eleitoral, e perceber a forma como dois jornais de polos ideológicos opostos se comportaram editorialmente perante os acontecimentos políticos em análise. Tudo isto tendo em mente que outros atos eleitorais (que não os acima mencionados) poderiam ter sido escolhidos para abordagem, caso das eleições legislativas de 1899, em que os republicanos venceram no Porto, beneficiados pelos danos eleitorais provocados nos partidos da Monarquia pela gestão da crise sanitária que teve lugar nesse mesmo ano na cidade.

Nas páginas dos periódicos ficou bem patente a vivacidade e o clima de efervescência político-social a que o Porto não ficou indiferente no período conturbado do reinado de D. Carlos que corresponde grosso modo ao do ocaso da Monarquia Constitucional portuguesa. $\mathrm{O}$ republicanismo esteve bastante ativo na região com os comícios que serviram de instrumento de propaganda eleitoral e com um órgão de comunicação social oitocentista/novecentista tão ativo como $A$ Voz Pública. Não deixa de ser assinalável a tendência que o Porto foi tendo ao longo do tempo para estar, política e socialmente, na vanguarda (quer pelo seu papel nas guerras liberais portuguesas de inícios de oitocentos, quer no fim do século com a tentativa de revolta republicana de 1891, duas décadas antes da revolta republicana vitoriosa de Lisboa, em 1910).

\section{Fontes}

\section{Fontes hemerográficas}

A Voz Pública. Porto, 19 e 24 de outubro/ 5, 17 e 19 de novembro de 1895 e 16, 17, 19, 20 e 21 de agosto de 1906.

O Comércio do Porto. Porto, 19 e 24 de outubro/ 5, 17 e 19 de novembro de 1895 e 16, 17, 19, 20 e 21 de agosto de 1906.

\section{Estudos}

ALMEIDA, Pedro Tavares de - Legislação Eleitoral Portuguesa: 1820-1926. Lisboa: Imprensa Nacional - Casa da Moeda, 1998.

CATROGA, Fernando; ALMEIDA, Pedro Tavares de (coord.) - Res Publica: Cidadania e Representação Política em Portugal (1820-1926). Lisboa: Biblioteca Nacional/ Assembleia da República, 2010.

LEAL, Manuel M. Cardoso - "A primeira experiência de representação orgânica no Parlamento em Portugal (1895-1897)". Estudos do Século XX. [Em Linha] Coimbra. ํo 
16 (2016), pp. 25-39. Disponível em WWW:<URL:https://doi.org/10.14195/1647$\underline{8622162}>\underline{ }$.

LEAL, Manuel M. Cardoso - "Eleições na Monarquia Constitucional: governos, partidos e opinião pública (1852-1910)”. Revista da FLUP: História. [Em Linha] Porto. IV Série, vol. $9, \quad \mathrm{n}^{\mathrm{o}} 2$ (2019), pp. 36-61. Disponível em WWW:<URL: https://ojs.letras.up.pt/index.php/historia/article/view/6596>.

LOPES, Fernando Farelo - "Caciquismo e Política em Portugal. Uma perspectiva sobre a Monarquia e a I República”. Sociologia-Problemas e Práticas. [Em Linha] No 9 (1991) pp. 127-137. Disponível em WWW:<URL:http:/hdl.handle.net/10071/1234>.

MALTEZ, José Adelino - Eleições de 1895. Maltez [Em linha]. [s.1]: Maltez, 2007. [s.num.]. Disponível em WWW:<URL: http://maltez.info/respublica/portugalpolitico/eleicoes portuguesas/1895.htm>.

MARQUES, A. H. de Oliveira (coord.) - "Portugal da Monarquia para a República". In SERRÃO, Joel e MARQUES, A. H. de Oliveira (dir) - Nova História de Portugal. Lisboa: Editorial Presença, vol. XI.

MÓNICA, Maria Filomena - “As Reformas Eleitorais no Constitucionalismo Monárquico, 1852-1910”. Análise Social. [Em Linha] Vol. XXXI, n. 131 (1996) pp. 1039-1084. Disponível em $\quad$ WWW: $<$ URL: http://analisesocial.ics.ul.pt/documentos/1223396410E4cIS9bh9Gh98WL9.pdf>.

PROENÇA, Maria Cândida - D. Manuel II. Rio de Mouro: Círculo de Leitores e Centro de Estudos dos Povos e Culturas de Expressão Portuguesa, 2005, p. 35-36.

RAMOS, Rui (coord.) - A Segunda Fundação (1890-1926). In José Mattoso (dir.) - História de Portugal. Lisboa: Editorial Estampa, vol. 6, 1994.

RAMOS, Rui - História de Portugal. Lisboa: A Esfera dos Livros, 2009.

SERRÃO, Joel (dir.) - Dicionário de História de Portugal. Lisboa: Iniciativas Editoriais, 1971, vol. IV, p. 2-8. 